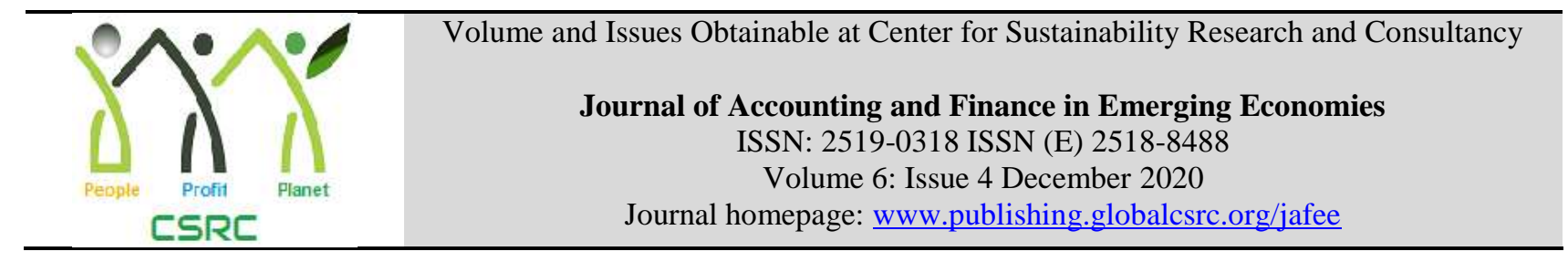

\title{
The Nexus of Currency Fluctuations on Imports and Exports of Pakistan
}

\author{
${ }^{1}$ Abid Khan, ${ }^{2}$ Ilyas Sharif, ${ }^{3}$ Shakeel Khan \\ ${ }^{1}$ QEC, University of Malakand, Pakistan, phdabid@gmail.com \\ ${ }^{2 \& 3}$ Lecturer, Quaid-e.Azam College of Commerce, Lecturer Institute of Management Studies \\ University of Peshawar, Pakistan, ilyasqacc@uop.edu.pk
}

\begin{tabular}{l} 
ARTICLE DETAILS \\
\hline History \\
Revised format: November \\
2020 \\
Available Online: December \\
2020
\end{tabular}

Keywords

Import, Export, Currency

Fluctuation, Exchange rate,

Stock Exchange, Pakistan.

JEL Classification:

M40, M48

\section{OPEN ACCESS}

ABSTRACT

Imports and exports are fulfilling the economic requirements and therefore in both productive ways it is highly demanding and efforts oriented to focus on the proper and effective ways of tackling these factors. Its representing that how Pakistani rupees value effects official debt, imports and exports an also study how it effects stock exchange/market. This research is supportive to examine the fluctuating factors and its role importantly for the development of drawing a clear and supportive economically benefiting policy for the wealth and progression in the fiscal and economic years. This research study was conducted to examine the impacts of currency fluctuations during the time period 2000 to 2010 (11 years) and these years have proved with some interested findings which are compatible with ground realities and positions and facts. The research study found that Pakistan's exports have significantly increased with the increasing devaluation or declining the monitory value of the Pakistan's currency. In addition it is also found explicitly the impact of currency fluctuation is positive and considerable on the exports in Pakistan during the time period 2000 to 2010 (11 years) while the impact on currency fluctuations on import is explicitly and implicitly found non related and insignificant. Therefore these findings are proving that imports are not related and found insignificant in relation with currency while the roles with exports are found quite supportive and recognizable. In this time series data OLS model in form of single linear regression has been applied to examine the influential impacts and recognizable factors for the research objectives.

(C) 2020 The authors, under a Creative Commons AttributionNonCommercial 4.0

Corresponding author's email address: ilyasqacc@uop.edu.pk

Recommended citation: Khan, A., Sharif, I. \& Khan, S. (2020).The Nexus of Currency Fluctuations on Imports and Exports of Pakistan. Journal of Accounting and Finance in Emerging Economies, 6(4), 1121-1131

\section{Introduction}

Currency rate stability and fluctuations both are reflecting the economic stability and instability in the market which are supportive for the valuable operations and growth towards the economic benefits of 
the firms. There are numerous possibilities of non compliance of the currency values towards the desired economic goals of the firms and therefore complex evaluative and significant assessments are necessary for the advancement and proactive measurement of currency values in the economic cycles (S. Bader, 2006). Devaluation is normally attempted as a method for redressing a deficiency to be decided of stability of expenses. As clear that some researchers are concerning that enervating the estimation of money can be really useful for the financial system in view that an extra fragile foreign money will guide trades, which thusly will carry employability and this can set in economic improvement and guide the financial system growth (Rahman, S. and Serletis, A.,2009). Devaluation of money has turned out to be extremely regular in the present age. Nations confronting monetary strains because of negative financial conditions have no option however to cheapen its money in order to push up its fares profit and at the same time to diminish imports. Such nations for the most part formally decline the estimation of their money in connection to gold just as other remote monetary standards. Determined antagonistic exchange equilibrium and disequilibrium in balance of payment are the first driver, that propels a nation to debase its currency. Real elements of exchange balance are exports and imports of a nation. Unfriendly exchange balance is usually the consequence of looseness in exchange distinction with imports.

Aizenman (2007) had given his view with respect to the effect of save property in limiting the genuine exchange rate instability in creating nations in case of exogenous terms of trade dumbfounds. Further explain that higher genuine conversion standard unpredictability is related with lower development, this infers higher reserves may advance development ultimately by lessening exchanges' measures instability. Aside from their effect on development, more elevated amount of assets is additionally connected with smoother capital record alteration showing their job in buffering value stuns. The exchange rates and profitability appear to conclusive in clarifying the differential business share for trades. The significance of the genuine powerful exchange scale for tariffs and trades of fabricated products in Africa has been shown by Ndulu and Semboja (1995), who discovered that the genuine compelling exchange rate affects fabricating exports. Among the components thought to impact send out intensity, is the genuine powerful exchange rate. Balassa (1990) set up a connection between the genuine successful exchange rates and exports of industrial products.

\section{Background of Study}

Imports and exports are fulfilling the economic requirements and therefore in both productive ways it is highly demanding and efforts oriented to focus on the proper and effective ways of tackling these factors. Therefore in light of the effective financial methodological ways the role of the currency fluctuation do possess strong meanings which in turn influence positive returns on the economic wealth and economic downfall in fiscal years.

Variations in different spheres and different modes are non effective to conclude results effectively although these are positively contributive; the reason is these influential and effective for better outcomes in both long and short runs which are recognized for the economic growth and economic development. Currency fluctuations in this connection are effective in this connection to examine for the financial position value of the currency and economic supportive outcomes. Currency imports are significant to fulfill the requirements of the current needs deficiencies and important.

\section{Study Objectives}

Study objectives are to know about role of currency devaluation on Pakistan's exports, imports and government concerns. Its representing that how Pakistani rupees value effects official debt, imports and exports an also study how it effects stock exchange/market. This research is supportive to examine the fluctuating factors and its role importantly for the development of drawing a clear and supportive economically benefiting policy for the wealth and progression in the fiscal and economic years. There are numerous and expandable growing chances available to pursue toward and effective growing outline for wealth management and development. Fluctuations are evidently found and these fluctuations do 
found in phases of times while significant factor is measure this fluctuation and proactively involved factor for the better consequences in form shaping right strategic approach for economic surplus. Therefore this research work is importantly considered in the entire process of the research which means currency fluctuations variations are truly considerable for the economic benefits and economic benefits are possible recorded through proper investigatory means.

\section{Study Limitations}

Following are the limitations of the study which is being faced in accumulation of the report:

$>$ The vast majority of the data is undocumented.

$>$ Concentrated on 2000 to 2010 just which is exceptionally unpredictable.

$>$ No direct data accessibility.

$>$ For the most part reliable on correct and ideal date with precisely right references

\section{Literature Review}

\subsection{Pakistan Currency Fluctuation}

Pakistan's economy is composed of a variety of industries including chemicals, textiles, sugar, food processing, agriculture and many more. Being the world's $25^{\text {th }}$ largest economy, Pakistan is currently on the verge of getting default. The economy is suffered a lot due to internal political clashes, a rapid growth in population, FDI and terrible confrontation with neighboring India. Nevertheless, IMFendorsed government strategies, supported by FDI and documented approaches to international markets, have made sturdy macroeconomic healing within the most up-to-date decade. Important macroeconomic revolution since 2000, most quite at privatization of the Banking sectors have helped the monetary system. Pakistan has seen a developing social class population from that time forward and poverty line has reduced by 10\% since 2001 (Ragoobur, V., and Emamdy, A. (2011). GDP development, driven by will increase in the modern as well as industrial sector, in 2004-06 it's in the range of 6-8\% limit. In the year 2005, the World Bank entitled Pakistan the most effective reformer in the regions and within the best ten reformers worldwide.

The ICT-Islamabad has persistently brought improvement defrayal in previous couple of years, as well as a 52\% real rise within the financial/budget allocation for advancement in fiscal year 2007, an elementary advance toward shift the expansive under development of its societal region. The economic/financial shortage - the consequence of continually low tax accumulation and rise in spending, including recreation prices from the staggering geographical region AJK quake in 2005 was reasonable.

Improvement in urban regions of Pakistan has stayed high however is low in rustic regions. The actual conversion rats estimates the money power while purchasing the external goods, in other words, its buying control over external products. The investigations of Lucas (1993), Biggs, Shah and Srivasta (1995), Bigsten et al. (1997), de Melo and Robinson (1990) and Edwards (1997), show observationally and hypothetically, that the exports of readymade items beneficially affect all factor of productivity. The currency interchange scale and efficiency appear to unequivocal in clarifying the differential stocks of the overall industry for exports and exports' goods. The significance of the genuine viable rates of exchange for exports of manufactured products in African countries has been exhibited by Ndulu and Semboja (1995), who found that the genuine compelling exchange rates impacts on exporting goods. The actual and significant currency exchange rates' are the factors which impact competitiveness of exports goods. Balassa (1990) built up a relationship between the produced merchandise and genuine currency interchange rates. Inflation; a severe risk to the financial system, reached to over $9 \%$ in 2005 which dropped to $7.9 \%$ in 2006 . After global rise in petroleum prices in 2008, inflation in Pakistan raised to as high as $25 \%$. The states bank is seeking after more tightly fiscal arrangement while endeavoring to safeguard development. Foreign exchange reserves holds are supported by stable employees' remittances, yet a developing current record shortage - driven by huge exchange difference as import increased surpasses export extension - could draw down reserve and reduce gross domestic product development in the medium terms. 
In the beginning of year 2008, the financial position of Pakistan has taken an emotional decline. The War against Terrorism have made instability and insecurity which leads to decline in FDIs from eight billion dollars to three and half billion dollars ( $\$ 8$ to $\$ 3.5 \mathrm{~B}$ ) for that financial period. Instantaneously, the rise up has restricted immense capital departure from Pakistan to the Arabs countries. Joined with excessive global object costs, the double impact has greatly surprised Pakistan's economy, with increasing alternate deficiencies, excessive enlargement and inflation withinside the estimation of the Rupee, which has tumbled from 90-1 USD to extra than 130s-1 USD in more than one months. Without precedent for years, it might need to look for outside subsidizing as Equalization of remittances bolster. Thusly, S \& P introduced down Pakistan's overseas foreign money debt score to CCC-further to from B, just a few ratings over a measurement that might show default. Pakistan's neighborhood foreign money debt score become introduced down to (B-) from (BB-). Credit agency Moody's investor carrier reduce its mindset towards Pakistan's debt to terrible from strong due to political vulnerability, but it saved up the country's comparing at B2. The fee of protection in opposition to a default in Pakistan's independent debt exchanges at 1800 points, as in step with its multiyear credit score default exchange, a measurement that indicates monetary specialists consider the country is as of now in or will earlier than lengthy be in default.

The study of Akhter and Hilton (1984) inspected the bidirectional exchange between United State of America and West Germany. The researchers discovered the exchange scale unpredictability has a huge negative influence on the imports and exports of two nations. Be that as it may, the unpredictability of conversion standard has been estimated by the standard deviation of successful trade rates. Gotur (1985) rejected the outcomes of Akhter and Hilton (1984). He included the countries in the Akhter and Hilton (1984) models are Japan, France, United Kingdom and expanding the example time frame and the proportions of exchange rates dangers. He didn't notice any critical connection between exchange rate instability and amount of exchange on the two-sided exchange streams. His outcomes is indistinguishable to IMF (1984) ponder on this issue. Chowdhury (1993) explored the effect of exchange rate unpredictability on the exchange streams of the G-7 nations in setting of a multivariate model inaccuracy adjustment. They discovered that the exchange rate unpredictability has a noteworthy negative effect on the volume of exports in every one of the G-7 nations. Baak, Mahmoud, and Vixathep (2002) researched the effect of exchange rate uncertainty on foreign trade in four East Asians nations (South Korea, Thailand, Singapore, and Hong Kong). Their outcomes demonstrated that exchange rate instability negatively affects exports in as side by side i.e. the short run and long run too.

\subsection{Imports of Pakistan In Connection with Currency Fluctuation}

Egert et al. examined the direct and indirect effect of exchange rate unpredictability by means of variations in exchange rate routines on the trade execution. Lourenco examined the global picture of exchange rate of 33 progressed and rising financial firms. Hussain et al. examined the stability and execution of substitute exchange rate of all IMF associated nations. Arize (1996) likewise suggested that negative substantial association between exchange rate volatility and imports and exports exists over the short run and long run. De Grauwe (1988) proposed that if the creation of model is precise, at that point of association between exchange rate instability and trade ought to be sure and significant. Ortega and Giovanni (2005) proposed experimentally the effect of trade cost on genuine exchange rate instability.

Freund and Pierola (2008) broke down more than ninety events of fabricated "export floods" and come to the point that trade floods in developing (yet not in developed) nations were related with vast genuine exchange rate downgrades that left exchange standard underestimated and with the coming of new export items and goals. Aizenman (2007) with respect to the effect of reserves in reducing the genuine exchange rate unpredictability in raising nations in case of exogenous terms of trade stuns. Given that higher genuine exchange standard instability is related with lower development, this infers higher reserves may advance development in indirect way by decreasing exchange rate unpredictability. Aside from their effect on development, larger amount of reserves is additionally associated with smoother capital record adjustments showing their job in buffering price staggers. Zhang (2000) says that price 
increase happens at last because of devaluing of the money. Virgil (2002) researched that the long run connection between Turkey's genuine exports and its exchange rate insubstantiality is negative yet measurably critical for Germany, France and the American. Smith (1999) expressed that the examination demonstrates that an expansion in exchange rate instability is set out alongside a decrease in universal relationships amongst bound and securities exchange.

\subsection{Exports of Pakistani Products in Connection with Currency Fluctuations}

A large number examinations have been researched the significant factors of import demand role for Least Developing Countries just as Developing Countries. In the global research standard, the ordinarily utilized import demand capacities has been examined in a wide range of research activities for a very long while, including Khan (1974) for fifteen rising nations, according to Arize and Afifi (1987) for thirty rising nations, Bahmani-Oskooee (1998) for 6 LDCs, and Sinha (2001) for 5 Asian countries. In addition, there have additionally been numerous investigations on particular nations, for example, Sinha (1997b) for Thailand, Tang (2002) and Sinha (1996) for India, Tang and Mohammad (2000) for Malaysia, Dutta and Ahmad (1999) for Bangladesh Raijal et al. (2000) for Nepal. The past examinations for Pakistan, for example, Sarmad (1989) evaluated import demand role for Pakistan amid the period 1959-60 to 1985-86 utilizing a general methodology and did not manage the issue of stationarity of the variables. Sinha (1997a) evaluated import demand role for Pakistan, performed stationarity and residual based co incorporation system created by Engle Granger (1987) on yearly time series data for the 19701993 era. Afzal (2001) evaluated import demand role for Pakistan utilizing the model of simultaneous equation, by utilizing (OLS) and Two Phase Least Square (2SLS) methods presenting the duration from 1960 to 1999 . In any case, Afzal (2001) likewise does not tried for the stationary of the information. Besides, the prior investigations for Pakistan utilized little example of yearly time series data and did not utilized instability of exchange rate as a determinant of import demands. There are just couple of studies, evaluated exactly import demands roe for Pakistan, utilizing respective exchange data, for example, Malik and Akhtar (2000) assessed reciprocal cost and income impacts on Pakistan's trading performance with its four noteworthy exchanging associates i.e. United State of America, United Kingdom, Japan and Germany. The three phase least square strategy was utilized quarterly data for the period 1982-1Q to 1996-4Q. Their outcomes show income versatility of imports from Japan and United State of America are side by side.

Khan (1974), and Naqvi et al. (1983), examined the performance of Pakistani imports and the same was also examined by Sarmad and Mahmood (1985), and Afzal (2001) and Hasan and Khan (1994). Neither of these papers has analyzed the time series properties, which is very charming because of the utilization of time series data. The aim of this paper is to think about the genuine and compelling exchange rate response of imports demands in Pakistan for the period 1960 to 2003 utilizing both traditional and time series econometrics method that may be of some support to detail a sensible exchange rate strategy.

\section{Methodology}

\subsection{Research Model}

The work proceeded through examining the proposed research theoretical framework and is based on the following mentioned research model

Import / Export $=$ Function of (Currency Fluctuation)

Model Import = Function (Currency Fluctuation)

Import $=$ B0 + B1 (Currency Fluctuation)

Model Export $=$ Function (Currency Fluctuation)

Export $=$ B0 + B1 (Currency Fluctuation)

\subsection{Research Hypothesis}

$\mathrm{H}_{0}$ a There is no significant relationship between currency fluctuations and imports of Pakistan

$\mathrm{H}_{1}$ a There is significant relationship between currency fluctuations and imports of Pakistan

$\mathrm{H}_{0} \mathrm{~b}$ There is no relationship between currency fluctuations and exports of Pakistan 
$\mathrm{H}^{1} \mathrm{~b}$ There is significant relationship between currency fluctuations and exports of Pakistan The research hypotheses are based on the proposed research theoretical framework that is planned to be tested to examine its fluctuating position in the time series data from 2000 to 2010.

\subsection{Sampling Approach}

The study aims achieved with the help of proposed research topic and inter connected stepwise approach. For this purpose primary and secondary data examined.

\subsection{Data Collection Tools}

There are varieties of tools and sources for primary data collection that are supportive the collection of the primary data and secondary data. Among these available options, the one was preferably webs source which was mainly important for the study.

\section{Results and Discussions}

The main process for the study has been initiated through integrated steps and these were found to pursue the research work through properly defined format. Therefore, all aspects are focused on the realistic outcomes and it based for the overall research objective and hypothesis testing to conclude the required outcomes properly. The main results are structured and different into different parts to properly explain and understand the result based activities in this whole process.

Table 4.1 Correlation Matrix

\begin{tabular}{llcl}
\hline Variables & Exchange Rates & Imports & Exports \\
\hline Exchange Rates & 1 & -.432 & $.708^{*}$ \\
Imports & -.432 & 1 & -.592 \\
Exports & $.708^{*}$ & -.592 & 1 \\
& & & \\
\hline
\end{tabular}

Correlation is significant at the 0.05 level (2-tailed) Pearson Correlations

Table 4.1 is explaining the correlation between Exchange for the time period of ten years and imports and exports in Pakistan. It is found that exchange rate that is showing the fluctuations in the time period of ten years in currency of Pakistan is proved negatively related with imported but with insignificant value of $\mathrm{P}$ that is showing the confidence interval. The confidence interval is although not acceptable, but closer to the required level and on the basis of this fact it is found that imports are negatively correlated with value of -0.432 this factor is very much low with unsatisfactory level of confidence therefore to consider it for the acceptance of hypothesis it won't be that much supportive to accept alternative hypothesis for influential relationship of currency fluctuations towards imports in Pakistan.

In addition the matrix correlation is stating that currency fluctuation influence the exports in Pakistan the value is found that 0.708 with level of significance 0.015 which means a positive correlation and acceptance for level of significance. Therefore to influence and mainly consider the main fact is found that the level of significance signifies that exports are positively improved in the time period of 2000 to 2010 which are 11 years in this 11 years time period although the currency value is declined comparatively than the dollars or in the international market but the impact is found supportive for the positive outcomes of the exports and value development.

The value for the export is exceeding with positive outcomes and it is found that there are many possible reasons behind this fact the currency value has been declined entire in the time period of 11 years and this improved the demands for the Pakistan goods in the international market with lower price. The lower price itself is found productive towards the impact for the good well and demands in the recent 
times therefore the role of exports with fluctuating value of the Pakistan's monitory value is supportive towards the better outcomes and better consequences.

These all and related structural activities are supportive for the acceptance of alternative hypothesis of the research currency fluctuations and exporting value of the research study.

Table 4.2 Regression

\begin{tabular}{|c|c|c|c|c|c|}
\hline \multirow[t]{2}{*}{ Model } & \multicolumn{2}{|c|}{ Unstandardized Coefficients } & Standardized & T-Test & Significance \\
\hline & B & Std. Erro & Beta & & \\
\hline (Constant) & $9.929 \mathrm{E} 10$ & $3.425 \mathrm{E} 10$ & & 2.899 & .018 \\
\hline Exchange Rates & $-7.583 \mathrm{E} 8$ & $5.276 \mathrm{E} 8$ & -.432 & -1.437 & .184 \\
\hline
\end{tabular}

a. Dependent Variable Imports

Table 4.2 explaining the significant role of the regression of the independent variable Exchange which is refereeing the 11 years currency fluctuations in Pakistan. It is seemed that there is a negative impact of imports found in Pakistan due the fluctuations in value of currency comparatively Pakistani currency has been declined and in the entire period of time the role of the imports has negatively been found but the significant and influential point is the significance level and t-test value which are found non supportive and unacceptable. The value of t-test is found non supportive with only reason that t-test value is below the standard value of the role of thumb which is standard of 2.00 and now this value is getting below that standard value is stating that the standard error figure is found higher in this relation and this situation.

These findings are supportive for the correspondence and acceptance of $\mathbf{H}_{0} \mathbf{a}$ Hypothesis and therefore the impact is found zero. Although this impact is negative but the hypothesis is not supported by the empirical evidences and which means non compliance and non supportive for the entire process the level of significance is found above the maximum limit of 0.10 and now it is 0.18 which means 82 percent is confidence level and this means this 82 percent confidence level is not enough to proceed and prove it for the acceptance level.

Table 4.3 Model Summary

\begin{tabular}{|c|c|c|c|c|c|}
\hline & \multirow[t]{2}{*}{$\mathbf{R}$} & \multirow[t]{2}{*}{ R Square } & \multirow{2}{*}{$\begin{array}{l}\text { Adjusted } \\
\text { R Square }\end{array}$} & \multirow{2}{*}{$\begin{array}{l}\text { Std. Error of the } \\
\text { Estimate }\end{array}$} & Change Statistics \\
\hline & & & & & R Square Change F Change Sig. F Change \\
\hline 1 & $0.432^{\mathrm{a}}$ & .187 & $1 .^{\prime}$ & $10 \mathrm{E} 10$ & 0.184 \\
\hline
\end{tabular}

a. Predictors (Constant), Exchange Rates

Table 4.3 explaining the role of $\mathrm{R}$ and R-Square, F-test and its significance level. The findings proved that is correlation exist between the imports and currency fluctuations which is not impressive and not influential at all. The value of $\mathrm{R}$ Square is only 18.7 percent so the variability in the dependent variable is only 18.7 percent while the rest 81.3 percent variability is due to other variables in the imports in Pakistan in the time period of 2000 to 2010 which are 11 years.

As for the value of F-test is concern it is found unacceptable at this level due to the lower value of F-test which 2.066 and the standard value is 4.00 this means the standard value shall be met or exceeded because to this is providing support for the acceptance of the model now to analyze all this it 
considerable that this figure is not acceptable at this level and therefore the impact is non contributive.

Table 4.4 Regression

\begin{tabular}{|c|c|c|c|c|c|}
\hline Model & Unstandarc & Coefficients & Standardized & T-Test & Significance \\
\hline & B & Std. Error & Beta & & \\
\hline (Constant) & $-9.819 \mathrm{E} 9$ & $9.352 \mathrm{E} 9$ & & -1.050 & 0.321 \\
\hline Exchange Rates & $4.337 \mathrm{E} 8$ & $1.440 \mathrm{E} 8$ & 0.708 & 3.011 & 0.015 \\
\hline
\end{tabular}

a. Dependent Variable Exports

Table 4.4 explaining the regression impact of exchange rate towards the exports. It is found that there is a positive impact of export found in Pakistan due the fluctuations in value of currency comparatively Pakistani currency has been declined and in the entire period of time the role of the imports has negatively been found but the significant and influential point is the significance level and t-test value which are found non supportive and unacceptable. The value of t-test is found supportive with only reason that t-test value is above the standard value of the role of thumb which is standard of 2.00 and now this value is getting below that standard value is stating that the standard error figure is found higher in this relation and this situation.

These findings are supportive for the correspondence and acceptance of $\mathbf{H}_{\mathbf{1}} \mathbf{b}$ Hypothesis and therefore the impact is positive. The hypothesis is not supported by the empirical evidences and which means a supportive compliance for the entire process the level of significance is found above the maximum limit of 0.015 and now it is almost 99.82 percent is confidence level and this means this is a strong level of confidence interval and proves it for the acceptance level.

Table 4.5 Model Summary

\begin{tabular}{l|l|l|l|l|lll}
\hline Model & $\mathbf{R}$ & R Square & $\begin{array}{l}\text { Adjusted } \\
\text { R Square }\end{array}$ & $\begin{array}{l}\text { Std. Error of } \\
\text { The Estimate }\end{array}$ & Change Statistics & & \\
\cline { 5 - 7 } & & & R Square Change & F Change & Sig. F Change \\
\hline 1 & $0.708^{\mathrm{a}}$ & 0.502 & $0.446 \quad 4.65270 \mathrm{E} 9$ & 0.502 & 9.066 & 0.015 & \\
\hline a. Predictors (Constant), Exchange Rates
\end{tabular}

Table 4.5 explaining the role of $\mathrm{R}$ and R-Square, F-test and its significance level. The findings proved that is correlation exist between the exports and currency fluctuations which is positive and impressive and influential at all. The value of $\mathrm{R}$ Square is 50.2 percent so the variability in the dependent variable is moderate and good at 50.2 percent while the rest 49.8 percent variability is due to other variables in the exports in Pakistan in the time period of 2000 to 2010 which are 11 years.

As for the value of F-test is concern it is found unacceptable at this level due to the higher than the standard value of rule of thumb which is value 9.066 and the standard value is 4.00 this means the standard value shall be met or exceeded because to this is providing support for the acceptance of the model now to analyze all this is considerable that this figure is not acceptable at this level and therefore the impact is contributive.

\section{Discussion}

Imports and exports are important factors or variable in any economy the economies are established with good and progressive outcome and these implements strong and effective basis to improve the economic procedural pathways for better outcomes. Therefore their roles are very significant and supportive to significantly apply and significantly analyzed for the uplift of the monitory values, progressions, economic stabilities and development in fiscal years in different spheres of times. In connections to all the impact is very important to get its considerations and implement the required economic planning and strategies for the uplift of the business initiatives and business development in different spheres of times. 
There are numerous activities that implement strong ties between international communities and among the two are imports and exports where different economies are linked properly their activities are structured and they supportively interconnected to perform highly supportive and progressive roles for the development of economies. These don't exist at a particular dimension of value; in this manner, a nation imports preferred items over local products, additionally to the extent promoting or packaging are concerned. These speak to an item diversity that is refreshing locally yet not made precisely in this flat or blended variation. These are less expensive abroad, since makers there are increasingly proficient, are looked by lesser prices, better adventure economies of scale as well as acknowledge bring lesser benefits. These are at the present local values, makers don't supply sufficient good or service as the demands requires, likewise as a result of abroad coordination issues; appropriately, purchasers purchase foreign for deficient local creation.

The research work has been proving the impact of influential factor the import and exports and they are proved with the facts that imports are providing non supportive and outcome with currency fluctuation in the time period of 11 years and so the impact is found zero or non supportive. The addition the impact of export from the export point of views are supportive because they are found with positive impacting value of beta and the rest of facts are also found supportive in this connection. The impact currency fluctuation from the exports point of views are proved with supportive initiative which means they are positively increased in the time period of 11 years while the role is declared as contributive mutually connected. Therefore their significance remained as important and cooperative to excel them for this research study. Imports and exports both are important contributors to improvingly consider for the research study. Imports are increasing the economic burden on the economy while exports are increasing the cash reserves, balance of payments and positive sign for the economic wealth and developments.

\section{Conclusion}

The research study has been conducted for the partial fulfillments of the degree requirements. In this research the researcher examined empirically the impact of currency fluctuation on the exports and imports. It is found that imports are non supportive and no correlation and regression is found due to insignificant values of regression and correlation for imports and currency fluctuation. In addition the role of currency fluctuation for exports are found well supportive in both aspects of correlation and regression and therefore it is found the currency fluctuation in the time period of 11 years from 2000 to 2010 has positively found the impact of currency fluctuations exports and thus they possess a significant position in this condition.

\section{References}

Al-Qudah, M.K.M., Osman, A. Halim, M.S.B and Al-Shatanawi, H. A., (2014). The effect of

human resources planning and training and development on organizational performance in the government sector in Jordan, International Journal of Academic Research in Business and Social Sciences, 4(4):79-85

Aycan,Z., Kanungo,R.N., Mendonca,M., Yu,K., Deller,J., Stahl,G., \&Khurshid,A.(2000). Impact

of culture of human resource practices: A 10 country comparison. Applied Psychology: An International Review, 49(1).

Arthur, J.B.(1994). Effects of Human Resource Systems on Manufacturing Performance and Turnover. Academy of Management Journal, 37(3).

Bae, J., and Lawler, J.J. (2000). Organizational Performance and HRM strategies in Korea: Impact on Firm Performance in an Emerging Economy. Academy of Management Journal, 43(3).

Bartel, (1994).Industrial Relations. A Journal of Economy and Society. ( 33) 4.

Becker, B.E. and Huselid, M.A. (1998). High Performance Work Systems and Firm Performance: A Synthesis of Research and Managerial Implications. Research in Personnel and Human Resource Management.

Brian Becker and Barry Gerhart, (1996). The Impact of Human Resource Management on 
Organizational Performance" Progress and Prospects. The Academy of Management Journal.39 (4).

Bernardin, H.J., Hagen, C.M., Kane, J.S. and Villanova, P. (1998). Effective performance management: a focus on precision, customers, and situational constraints. In Smither, J.W. (eds.), Performance Appraisal: State of the Art in Practice, San Francisco: Jossey-Bass.

Bernardin, H.J. and Russell, J.E.A.1993. Human Resource Management: An Experiential Approach, Singapore: McGraw-Hill Inc.

Caliskan, N. E. (2014). The impact of strategic human resource management on organizational performance, Journal of Naval Sciences and Engineering, 6(2): 100-116.

Chadwick C, Way SA, Kerr G, Thacker JW. 2013. Boundary conditions of the high-investment human resource systems small firm labor productivity relationship. Personnel psychology 66(2): 311-343.

Dessler, G. (2008). Human Resource Management (11 ${ }^{\text {th }}$ edition), New Delhi, Prentice Hall, of India Private Ltd.

Huselid,(1996). The Impact of HRM Practices on perceived Organizational Performance, USA. Academy of Management Journal. vol. 39(4).

Frye, MB. (2004). Equity Based Compensation for Employees: Firm Performance and Determinants. J. Financ. Res., 27(1).

Ghebregiorgis, F, Karsten, L. (2006). Human resource management practices in Eritrea: Challenges and prospect. Employee Relation. 28(2).

Gabriel, J. M. O. (2014). Social justice (SJ) and sustainable national development in Nigeria. International Journal of Advanced Research in Statistics, Management and Finance. 2(1):135143.

Gerhart, B. et al. (2007). Fundamentals of HRM.New York, The McGraw hill companies, Inc.

Guest, D. (2002). Human Resource Management, Corporate Performance and Employee Wellbeing: Building the Worker into HRM. The Journal of Industrial Relations. 44(3).

Holzer, H. J. (1987). Job search by employed and unemployed youth. Industrial \& Labor Relations Review. 40 (4).

Hong et al.,(2012).An Effectiveness of Human Resource Management Practices, Malaysia.

Huselid, M. A. (1995). The impact of human resource management practices on Turnover, productivity and Corporate Financial Performance. Academy of Management Journal. 38(3).

Hong T. M. Bui Gordon Liu Sarah Footner, (2016),"Perceptions of HR practices on job Motivation and work-life balance: mixed drives and outcomes in a labor-intensive sector", International Journal of Manpower, Vol. 37, No. 6 pp. 12-18.

Khan, M.A (2010).Effects of Human Resource practices on organizational performance.An empirical study of Oil and Gas industry in Pakistani. European Journal of Economics Finance and Administrative Sciences. 24.

Khalid, M. M., Rehman, C. A., Ilyas, M. (2014). HRM Practices and Employee Performance in Public Sector Organizations in Pakistan: An Empirical study. International Journal of Management Sciences and Business Research, 3(2), 69.

Khan et al., (2010). The Impacts of Organizational Commitment on Employee Job Performance. European Journal of Social Sciences. vol 15(3) 292.

Khatri N., (1999). "Emerging issues in Strategic HRM IN Singapore. International Journal of Manpower. vol. 20(8).

Khanum, A., 2013. An Overview of Pakistani Women in Education, Science and Research.

Kulik, C.T. (2004). Human resources for the non HR manager. Mahwah, NJ: Lawrence Erlbaum Associates.

Milkovich, George T. and Newman, Jerry M. (1999): Compensation, $6^{\text {th }}$ Ed., USA: Irwin McGraw-Hill.

Osterman, P. (2014). How Common is workplace transformation and who adopts it? Industrial And Labor relations Review, Vol 47, pp 173-188.

Patterson, P., Johnson, L., and Spreng, R. (1997). Modeling the Determinants of Customer 
Satisfaction for Business-to-Business professional services. Journal of the Academy of Marketing Science. 25 (1).

Pfeffer, J.(1994). Competitive advantage through people. Boston: Harvard Business School Press.

Ruwan, A., (2007). The Impact of Human Resource Practices on Marketing Executive Turnover of Leasing Companies in Sri Lanka. Contemporary Management. Review. 3(3).

Stirpe, L. Bonache, J., and Trullen, J. (2015), "The acceptance of newly introduced HR practices: Some evidence from Spain on the role of management behavior and organizational climate", International Journal of Manpower, Vol. 36 No. 3, pp. 334-353

Tabiu, A., and Nura, A.A. (2013). Assessing the effects of human resource management (HRM) practices on employee job performance: A study of Usmanu Danfodiyo University Sokoto. Journal of Business Studies Quarterly, 5(2), 247-259.

Tessema, M. and Soeters, J. (2006). Challenges and prospects of HRM in developing countries: Testing the HRM-performance link in Eritrean civil service. International Journal of Human Resource Management.17(1).

Uysal, G., \& Koca, G. (2009). HR and firms performance at companies in Turkey. A corrective analysis. Journal of Modern Accounting and Auditing. 5(1).

Wood, S.J. Human resource management and performance (1999). International Journal of Management Reviews, (1)

Wernerfelt, B. (1984). A Resource-based view of the firm. Strategic Management Journal, 5(2).

Wright et al.,(2003). The impact of HR practices on the performance of business units. Human Resource Management Journal. 13(3). 